\title{
Ohar bat bi patologikotasun-iturri dituzten hizkuntzei buruz
}

\author{
José MarTíneZ-FeRnÁNDEZ
}

(UB)

Genoveva Martí

$(\text { ICREA-UB })^{*}$

\section{(A note on languages with two sources of pathologicality)}

Joana Garmendiak ingelesetik itzulia.

DOI: $10.1387 /$ gogoa.20366

\begin{abstract}
We will consider languages that contain two different sources of semantic pathologies: sentences that do not express a proposition and sentences that, even though they do express a proposition, are neither true nor false. When those languages are given a three-valued semantics, all pathological sentences are lumped together and assigned the third truth value. In this paper we will first present the case of languages with definite descriptions, where a distinction between these two forms of pathological sentences can be drawn. Then we will explore a four-valued semantics which can distinguish between the two kinds of pathological sentences.
\end{abstract}

Keywords: definite descriptions, gappy sentences, four-valued logic, Kleene logic, order $Y 4$.

* Espainiako Economía y Competitividad ministerioaren laguntza jaso dugu lan hau egiteko, Localism and globalism in logic and semantics (FFI2015-70707-P) proiektuaren bidez. 


\section{Laburpena}

Patologia semantikoen bi iturri desberdin dituzten hizkuntzetan jarriko dugu arreta: proposizio bat adierazten ez duten perpausetan eta, proposizio bat adierazten duten arren, ez egiazko eta ez faltsu diren perpausetan. Hizkuntza horiei hiru baliodun semantika bat ematen zaienean, perpaus patologiko guztiak bildu egiten dira eta hirugarren egibalioa esleitzen zaie. Lan honetan, hasteko, deskripzio definitudun hizkuntzen kasua aurkeztuko dugu; horietan, marraz daiteke bi perpaus patologiko mota horien arteko bereizketa. Gero, lau baliodun semantika bat arakatuko dugu, perpaus patologikoen bi motak bereiz ditzakeena.

Gako-hitzak: deskripzio definituak, hutsartedun perpausak, lau baliodun logika, Kleene logika, Y4 ordena.

Jesus Mari Larrazabal izan da Euskal Herrian logikaren eta filosofiaren alorretan puntako ikerketa bikaina sendotu duen indarra. José Martínezen tesiko epaimahaian izan zen Jesus Mari eta, orduz gero, beti eman dio babesa bere ibilbide akademikoan, aholku emanez eta aztertzeko ideia berriak proposatuz. Josék eta Genovevak, biek ala biek, harreman bizia izan dute urteetan zehar Jesus Marik sorturiko ikerketa-talde paregabearekin. ILCLI giltzarri izan da filosofiaren eta ezagutza-zientzien esparru askotarikoen arteko diziplinarteko ikerketa eta elkarlana babesteko eta bultzatzeko. Elkarlan horren adibide da lan hau. Atsegin handiz hartu dugu parte Jesus Mari Larrazabalen ibilbidea ospatzeko egindako ale honetan.

\section{Sarrera}

Hiru baliodun logikak erabili ohi dira hutsartedun hizkuntzak formalizatzeko; hau da, interpretaturiko hizkuntzak, zeinetan perpausak izan daitezkeen egiazkoak, faltsuak edo ez bat eta ez beste. Egibalioetan hutsarte bat sartzeko arrazoiak hauetakoren bat kontuan hartzetik sortu ohi dira: paradoxa semantikoak, denotaziorik eza, aurresuposizio-akatsak, eta abar. Lan honetan, bi motatako hutsartedun perpausak sortzen dituzten patologia semantikoen bi iturri desberdin dituzten hizkuntzen formalizazioan jarri dugu arreta: (i) proposizio bat adierazten ez dutelako egibalio klasikorik ez duten perpausak eta (ii) proposizio bat adierazten duten arren, gabeziaren bat (izan semantikan edo munduko gertaeretan) dela-eta ez egiazko eta ez faltsu diren perpausak. Lehenengo atalean, hutsartedun perpausen bi mota horien arteko bereizketa erakusten duen kasu bat aurkeztuko dugu; bigarren atalean, bi hutsartetasun motak errepresenta ditzakeen lau baliodun semantika baten zirriborroa egingo dugu. 


\section{Deskripzio definituen erabilera erreferentziala eta atributiboa}

Deskripzio definituen erabilera erreferentzialaren eta atributiboaren arteko bereizketa Keith Donnellanek proposatu zuen «Reference and Definite Descriptions» artikulu eragin handikoan. Donnellanen esanetan, «deskripzio definitu bat (...) atributiboki erabiltzen duen hiztunak honakoa-ta-halakoa den edonori edo edozeri buruzko zerbait baiezten du. Deskripzio definitu bat erreferentzialki erabiltzen duen hiztunak (...) entzuleak nori edo zeri buruz hitz egiten ari den identifikatzeko erabiltzen du deskripzioa, eta pertsona edo gauza horri buruzko zerbait baiezten du» (1966: 285). Bestela esanda, F-aren erabilera atributiboak, $F-a$ $G$ da esaldian, $F$ bakarra izatea baldintza dakarkio esaldiaren egibaldintzazko edukiari: index bakoitzean $\mathrm{F}$ bakarra zer edo nor den, horren araberakoa izango da egibalioa, eta entitate horrek G propietatea izatearen araberakoa. Bestalde, deskripzio definitu baten erabilera erreferentzialak egibaldintzei egiten dien ekarpena objektu bat da; $a$, esate baterako. Halaber, kasu horretan, index bakoitzean $a G$ den edo ez den, horren araberakoa izango da egibalioa.

Egituratutako proposizioen tresna baliatzen badugu, esan dezakegu deskripzio definituen erabilera atributiboek proposizio orokorrak sortzen dituztela; proposizio horiek, tradizionalki, honako forma hau balute bezala irudikatu dira: $<! F^{*}, G^{*}>$ (non '! $F^{*}$ 'k «F bakarra izatea» baldintza errepresentatzen duen). Bestalde, erabilera erreferentzialek proposizio singularrak sortzen dituzte, $<a, \mathrm{G}^{*}>$ forma balute bezala irudika daitezkeenak.

Donnellanen arabera, erabilera erreferentzialen bereizgarri da erreferi diezaieketela deskripzioa asetzen ez duten objektuei. Hortaz, bere adibide ezagunean, «martinia edaten ari den gizona» erreferentzialki erabil daiteke zer eta ura edaten ari den norbait hautatzeko. Erabilera erreferentzialen funtsezko ezaugarri hori aurkezteko modu horrek zera aldarrikatzera eraman du bat baino gehiago; alegia, Donnellanen bereizketa pragmatikoa dela soil-soilik. Ikuspuntu nahiko hedatu horren arabera, deskripzio definituak dituzten perpausek $<! F^{*}, G^{*}>$ forma duten proposizioak adierazten dituzte beti.

Hala eta guztiz ere, zenbait semantikarik atzeman dio semantikaren mailan garrantzirik Donnellanen bereizketari. Horien artean, David Kaplani (1978) eta Howard Wettsteini (1981) zor diegu erabilera erreferentzialen eta atributiboen arteko desberdintasunaren interpretaziorik zabalduena. Kaplan eta Wettsteinen arabera, erreferentzialki erabilitako deskripzio definitu bat erakuste baten antzekoa da. Esate baterako, behatzaz patata-zaku bat seinalatuz eta erakutsiz «hori astuna da» esaten duen hiztun batek adierazten du proposizio bat non patata-zaku jakin hura den «hori» esateak egibalioei egiten dien ekarpena. Eredu horren arabera, esaterako, "Lurra orbitatu zuen lehen pertsona ausarta zen» perpausean deskripzioa erreferentzialki erabiltzea eta Yuri Gagarin seinalatuz «hura ausarta zen» esatea baliokide dira. Ga- 
garin pertsona ausarta zen edo ez, horrek mugatzen ditu adierazitako baieztapenaren egibaldintzak, bai hemen eta bai ezein mundu posibletan, nahiz eta, zenbait ebaluazio-indexen arabera, hura ez izan Lurra orbitatu zuen lehen kosmonauta.

Halere, Kaplanek eta Wettsteinek erabilera erreferentzialen garrantzi semantikoaz egiten duten interpretazioa ez zaio erabat leial Donnellanek erabilera erreferentzialen bereizgarritzat nabarmendu zuenari. Erakuste batek, erakutsitako objektua aukeratzen du; era berean, erakusle baten gisara erabilitako deskripzio batek deskripzioa asetzen duen objektu bat aukeratzen du. Beraz, Kaplanen eta Wettsteinen interpretazioaren arabera, erreferentzialki erabilitako deskripzio definituek ez diete inoiz egiten erreferentzia deskripzioa asetzen ez duten objektuei. Aitzitik, bada, haien hurbilpenean, desberdintasun argi bat erabilera erreferentzialek eta atributiboek dakarten egibaldintzazko edukian.

Kaplani eta Wettsteini jarraitzen badiegu Donnellanen bereizketak semantikan duen garrantziaz egiten duten interpretazioan, interesgarria da galdetzea zer gertatzen den deskripzio definituak kale egiten badu denotatzean. Demagun espazioko egitasmoa ez zela inoiz abiarazi, eta ez duela gizaki batek ere inoiz Lurra orbitatu. Kasu horietan, argi dago, interpretazio atributiboa eginez gero, adierazitako proposizioak barne hartzen duela konposatu atributibo bat zeinak ez duen, mundu honetan, objekturik edo banakorik aukeratzen, baina aukera dezakeen objekturen bat beste mundu batzuetan. Kasu horietan egibalioak esleitzeari buruz jarrera strawsondarra hartzen badugu, proposizioak ez dauka egibaliorik, baina ezin da ukatu esaldiak adierazitako proposizio erabat osatu bat badenik. Aitzitik, deskripzioa erreferentzialki erabiltzen bada, kasua erakuste batek huts egiten duenaren antzekoa da, eta ez dago seinalatzen den ezer.

$F-a G d a$ formako perpaus batek, non deskripzio definitua atributiboki erabili den, $<! \mathrm{F}^{*}, \mathrm{G}^{*}>$ formako proposizio bat adierazten du; proposizio hori, ebaluazio-index bakoitzean, egiazkoa, faltsua edo egibaliorik gabea izan daiteke. $F-a$ $G d a$ formako perpaus batek, non deskripzio definitua erreferentzialki erabili den, $<a, G^{*}>$ formako proposizio bat adierazten du, baldin eta ak asetzen badu «F bakarra izatea». Baina banako edo objektu bat ere ez bada $F$ bakarra, proposizioak osagai bat falta du, eta ez dago proposizio osorik ebaluatzeko.

\section{Zenbait semantika balioaniztun Y4 ordenan}

Lehenengo atalean, bi motatako perpaus hutsartedunak sor ditzakeen fenomeno semantiko bat aurkeztu dugu. Perpaus hutsartedunek arrazoi desberdinak direla medio ez badaukate egibaliorik, eta, arrazoi horien ondorioz, modu desberdinetan jokatzen badute konektagailu logikoak daudenean, ba- 
lio semantiko desberdinak esleitu beharko genizkieke. Ondorioz, lau baliodun interpretazio-eskema bat erabili beharko genuke. Beraz, har ditzagun balio semantikotzat $\mathrm{E} 4=\{0,1,2,3\}$ taldeko osagaiak; Ori «faltsua» balioa dagokio eta $1 \mathrm{i}$ «egiazkoa». 2 eta 3 perpaus hutsartedunentzat gordeko ditugu. 3 esleituko diegu proposizio bat adierazten ez dutelako egibalio klasikorik ez duten perpausei, eta 2 esleituko diegu proposizio bat adierazten duten perpausei, baina egitateek determinatzeke uzten dutenean proposizio hori egiazkoa ala faltsua den. Itzul gaitezen, bada, gure fikziozko kasura: ez du inoiz gizaki batek ere Lurra orbitatu. Kasu horretan, «Lurra orbitatu zuen lehen pertsona ausarta zen» esaldiaren egibalioak, deskripzio definituaren interpretazio atributiboaren baitan, 2 balioa du; deskripzio definituaren interpretazio erreferentzialaren baitan, 3 balioa du. Naturala da lau baliodun logikarik garrantzitsuena aintzat hartuz hastea: Belnap-Dunnen logika (FDE ere baderitzona), Kleeneren logika Gogorra orokortzen duena. Halere, erraza da ikustea logika horren interpretazio estandarrek ez dutela balio aplikazio honetarako.

Belnap-Dunnen logikari bi interpretazio nagusi eman ohi zaizkio: interpretazio dialetheistak 3 balioa esleitzen die bai egiazko eta bai faltsu diren perpausei (asebeteak); eta 2 balioa, aldiz, ez egiazko ez faltsu diren perpausei. Perpaus hutsartedun guztiei egibalio bera esleitzen dienez, interpretazio horrek ez du balio hemen. Beste interpretazio garrantzitsu batek balio epistemikotzat hartzen ditu lau balioak. Interpretazio hori egokia da datu-base eta ordenagailuentzat, baina hori ere ez da hemen aplikatzeko modukoa. Belnap-Dunnen operatzaileen arazo nagusia zera da, $2 \wedge 3=0,2 \vee 3=1$ dela, eta egibalioen esleipen horrek justifikaziorik gabea dirudi baldin eta 2 eta 3 perpaus hutsartedunentzako balioak soilik badira: zergatik izan behar luke (oro har) faltsua ez egiazko eta ez faltsu diren bi perpausen konjuntzioak?

Non hasi behar genuke arrazoizko logiken bila? Hasteko, honako hau izango dugu kontuan: Belnap-Dunn logikaren operatzaileek monotonikoak izan behar dutela E4ko informazio-ordenan, non 2 den osagairik txikiena, 3 handiena, eta 0 eta 1 erdibideko balio konparaezinak diren. E4ko balioez guk egin dugun interpretazioan, ordena horrek ez du zentzurik. Perpaus baten egiazkotasunari edo faltsutasunari buruzko informazio-maila islatzen duen ordena bat honako hau litzateke, Y4 esango dioguna:

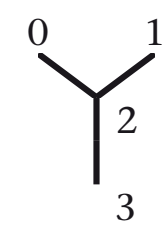

Naturala da perpaus hutsartedunen bi iturri dituzten hizkuntza balioaniztunetako operatzaile logikoei eskatzea Y4n monotoniko izateko. Halaber, normalak ere izan behar lukete; alegia, balio klasikoei aplikatutakoan da- 
gokien operatzaile klasikoak bezala jokatu behar lukete. Bi baldintza horiek hiru operatzaile posible mugatzen dituzte ukazioarentzat:

\begin{tabular}{c|ccc} 
& $\neg_{1}$ & $\neg_{2}$ & $\neg_{3}$ \\
\hline 0 & 1 & 1 & 1 \\
1 & 0 & 0 & 0 \\
2 & 2 & 2 & 3 \\
3 & 3 & 2 & 3
\end{tabular}

Begi-bistakotzat jotzen dugu proposizio bat adierazten ez duen perpaus baten ukazioak ere ez duela proposizio bat adierazten; eta azpideterminaturiko perpaus baten ukazioa ere azpideterminatua dela. Beraz, irmotasun filosofikoak behartzen gaitu $\urcorner_{1}$ erabiltzera ukazioaren interpretaziotzat.

Konjuntzioarentzat operatzaile posibleak mugatu nahi baditugu, eskatu beharko genieke izan daitezela, Y4n normal eta monotoniko izateaz gain, baita trukakor, elkarkor eta idenpotente ere. Konjuntzioaren kasuan, erraza da egiaztatzea bost operatzaile daudela bost baldintzak asetzen dituztenak ${ }^{1}$ :

\begin{tabular}{l|llll}
$\wedge_{1}$ & 0 & 1 & 2 & 3 \\
\hline 0 & 0 & 0 & 2 & 3 \\
1 & 0 & 1 & 2 & 3 \\
2 & 2 & 2 & 2 & 3 \\
3 & 3 & 3 & 3 & 3
\end{tabular}

\begin{tabular}{c|cccc}
$\wedge_{2}$ & 0 & 1 & 2 & 3 \\
\hline 0 & 0 & 0 & 0 & 3 \\
1 & 0 & 1 & 2 & 3 \\
2 & 0 & 2 & 2 & 3 \\
3 & 3 & 3 & 3 & 3
\end{tabular}

\begin{tabular}{c|cccc}
$\wedge_{3}$ & 0 & 1 & 2 & 3 \\
\hline 0 & 0 & 0 & 0 & 0 \\
1 & 0 & 1 & 2 & 3 \\
2 & 0 & 2 & 2 & 3 \\
3 & 0 & 3 & 3 & 3
\end{tabular}

\begin{tabular}{c|cccc}
$\wedge_{4}$ & 0 & 1 & 2 & 3 \\
\hline 0 & 0 & 0 & 2 & 2 \\
1 & 0 & 1 & 2 & 2 \\
2 & 2 & 2 & 2 & 2 \\
3 & 2 & 2 & 2 & 3
\end{tabular}

\begin{tabular}{c|cccc}
$\wedge_{5}$ & 0 & 1 & 2 & 3 \\
\hline 2 & 0 & 0 & 0 & 0 \\
1 & 0 & 1 & 2 & 2 \\
2 & 0 & 2 & 2 & 2 \\
3 & 0 & 2 & 2 & 3
\end{tabular}

Operatzaile horietako bat dagoeneko ezaguna da literaturan: $\wedge_{2}$ Melvin Fittingek (1994) definituriko konjuntzio-operatzailea da. Bat dator Kleene konjuntzio gogorrarekin $\{0,1,2\} \mathrm{n}$, eta Kleene konjuntzio ahularekin $\{0,1,3\} \mathrm{n}$. $\wedge_{1}$ operatzailea bat dator Kleene konjuntzio ahularekin, bai $\{0,1,2\}$ n eta bai $\{0,1,3\}$ n. Era berean, $\wedge_{3}$ operatzailea bat dator Kleene konjuntzio gogorrarekin bai $\{0,1,2\} \mathrm{n}$ eta bai $\{0,1,3\} \mathrm{n}$. $\wedge_{3} \mathrm{k}$ azken propietate hori partekatzen du Belnap-Dunn konjuntzioarekin; bien arteko aldea zera da, $2 \wedge_{3} 3=3$ dela, eta horrela konpontzen da Belnap-Dunn konjuntzioan atzemandako anomalia. Hiru operatzaile horietatik edozein erabil liteke perpaus hutsartedunen

\footnotetext{
${ }^{1}$ Gehiegi ez luzatzearren, konjuntzioari buruz soilik ariko gara hemen. Disjuntzioa eta baldintzatzaile materiala gisa bertsuan jorra daitezke.
} 
bi iturri dituzten hizkuntzetan konjuntzioa formalizatzeko. Aukera honetan datza: jarrera «gogorra» edo «ahula» hartzen ote dugun bi motatako perpaus hutsartedunekiko. Normalean, argudiatu ohi da indeterminazioa eta Kleene operatzaile gogorrak eskuz esku doazela, eta esanahi-gabezia egoki formalizatzen dela Kleene operatzaile ahulekin. Beraz, 2 eta 3 balioentzat ditugun interpretazioen arabera, naturala litzateke $\{0,1,2\}$ ko murrizketa Kleene gogor gisara hartzea, eta $\{0,1,3\}$ ko murrizketa Kleene gogor edo ahul gisara -zeraren arabera, ea nola hartu nahi ditugun proposiziorik adierazten ez duten perpausak proposizioak adierazten dituzten perpausekin konjuntzioan daudenean- Horrek $\wedge_{2}$ eta $\wedge_{3}$ operatzaileetara murriztuko lituzke gure aukerak. Gainerako bi operatzaileak, $\wedge_{4}$ eta $\wedge_{5}$, bat datoz $\{0,1,2\}$ n Kleene konjuntzio gogor eta ahularekin, hurrenez hurren; baina konjuntzio mota berri bat ematen dute $\{0,1,3\}$ n. Gehiago hausnartu beharko litzateke ikusteko ea baduten aplikazio interesgarririk. Ohartzen gara $\wedge_{1}$ and $\wedge_{2}$ operatzaileak ere monotonikoak direla Belnap-Dunn informazio-ordenan.

Etorkizunean aztertuko ditugu bi hutsartetasun moten iturri gehiago; esate baterako, aurresuposizio-akatsak, oker kategorikoak, baldintzazko baieztapenak eta paradoxa semantikoak. Halaber, aztertuko dugu zein propietate formal dituzten goian aipaturiko hizkuntza formaletan defini daitezkeen logikek, ondoriotasuna egia gordetze gisa definitzen denean.

\section{Erreferentzia bibliografikoak}

Donnellan, Keith (1966), «Reference and Definite Descritpions». The Philosophical Review 75 (3): 281-304. [Euskarazko itzulpena, Kepa Kortak ingelesetik egina, honako liburu honen 7. kapitulua da: K. Korta (atontzailea) (2007), Hitzaren Lilura. Hizkuntzaren Filosofiako Irakurgaiak, Bilbo: UPV/EHU, 173-194 or.].

FitTing, Melvin (1994), «Kleene's three-valued logics and their children». Fundamenta Informaticae 20: 113-131.

KaPlan, David (1978), «Dthat». In Peter Cole (arg.), Syntax and Semantics. New York: Academic Press, 221-243.

WetTSTeIn, Howard (1981), «Demonstrative reference and definite descriptions». Philosophical Studies 40 (2): 241-257. 



\title{
Ohar bat intentzionalitatearen trataezintasunaren inguruan
}

\author{
JEAN-MiCHEL ROY \\ Lyon (Frantzia) eta Shanghai (Txina)
}

\section{(A note on the intractability of intentionality)}

Ekain Garmendiak ingelesetik itzulia

DOI: $10.1387 /$ gogoa.20367

\begin{abstract}
Even though some of Putnam's particular proposals have had a huge impact on the philosophical discussion regarding the nature of intentionality, he does not offer anywhere a general theory that would offer a general account of the nature of intentionality. The main goal of the present paper is to explain Putnam's own diagnostics on the alleged «intractability» of intentionality. As it is explained in the article, according to Putnam, within a particular naturalistic framework intentionality has become intractable, but such intractability is not due to some tension between intentionality and naturalism themselves, but due to a cartesian intentionalism developed in the seventeenth century inherited and assumed by most of the naturalistic accounts nowadays.
\end{abstract}

Keywords: Putnam, intentionality, naturalism, cartesianism, realism.

\section{Laburpena}

Hilary Putnamek egindako proposamen konkretu batzuek intentzionalitateari buruzko gogoeta filosofikoan eragin izugarria izan badute ere, ez du inon ematen intentzionalitatearen auziari orokorrean helduko dion teoria osorik. Testu honen helburu nagusia da Putnamek intentzionalitatearen «trataezintasunaren» inguruan egiten duen diagnostikoa argitzea. Testuan azaltzen denez, Putnamen iritziz, marko naturalista partikular baten barnean intentzionalitatea trataezin izatera iritsi da, baina intentzionalitatearen izaera trataezin hori ez da intentzionalitatearen eta naturalismoaren artean berez legokeen halako tentsio batengatik, baizik eta gaurko jarrera naturalista gehienek jaso eta onartzen duten hamazazpigarren mendeko intentzionalismo kartesiar batengatik.

Gako-hitzak: Putnam, intentzionalitatea, naturalismoa, kartesiarnismoa, errealismoa. 
Intentzionalitatearen gaia gogoeta filosofikoaren eremu ugariren erdigunera itzuli zen, batez ere gogoaren eta kognizioaren filosofian, hirurogeiko hamarkadaren hasieran izan zen konduktismo logikoaren aurkako erantzunaren eraginez. Nahikoa adostasun dago intentzionalitatearen arazo horren alderdi desberdinen gaineko interesaren berpizte hori dela-eta izan ziren eztabaiden geografia teorikoari dagokionez. Salbuespen nagusi bat badago, nolanahi ere: zaila da Hilary Putnamen iritziak paisaia intentzionalista horretan zehatz kokatzea.

Esan liteke badagoela halako paradoxa bat Putnamen inguruan, auzi honi dagokionez. Alde batetik, onartu ohi da Putnam dela izaera intentzionala daukaten gogo-egoeren naturalizazioari buruzko funtzionalismo konputazionalistaren aita (ikus Putnam 1967), baita horien eduki intentzionalaren indibiduazioari buruzko externalismo klasikoaren aita ere (ikus Putnam 1975) —eta horri lotua dagoen eduki estu eta zabalen arteko bereizketarena ere bai-, eta, horrenbestez, eztabaida hauetan parte hartzen duten protagonisten artean nagusi eta identifikagarrienetakotzat jo ohi da. Nolanahi ere, ezaugarritze bikoitz hori ez da intentzionalitatearen arazoaren trataera oso izatera iristen eta, horregatik, itzalean uzten du akaso Putnamek garatutako arazoaren irudi osoago bat; eta, beraz, beharrezko suertatzen da Fodor batek, Dennett batek edota Searle batek emandako ikuskera antzera osoagoekin erkatzea. Badaude arrazoi onak are zalantzan ere jartzeko ea ba ote daukan Putnamek guztiz garatutako intentzionalitatearen teoria baten gisako zerbait. Zehazki, eta goraxeago aipatutako autoreek ez bezala, gutxitan hitz egiten $\mathrm{du}$ intentzionalitatearen arazoa bere kezka nagusia izango balitz bezala. Izan ere, liburu bakarra dauka zuzenean eta osoki intentzionalitatearen gaiari bere horretan emana (ikus Putnam 1988), eta bere izena gutxitan agertzen da autore horien ondoan intentzionalitatearen teoriko sistematiko garaikide nagusiak aipatzen direnean.

Horretaz gain, eta nahiz eta zuzena izan intentzionalitatearen arazoari Putnamek egiten dion hurbilketa egoera intentzionalen indibiduazioaren eta naturalizazioaren gai zehatzen gainean dauzkan iritzietara murriztea, bere lehen aroan proposatu zituenek ez dute lortzen gai horien inguruko bere ikuskera atzematea, urteek aurrera egin ahala bere gogoeta filosofikoa nabarmen aldatu baitzen, jakina denez. Eta intentzionalitatearen arazoaren inguruan berak esplizituki gehien landu zituen alderdi horiek behin eta berriz moldatu izanak ere zaildu egiten du argitzea zein den arazo horren inguruan daukan ikuskera orokorra.

Badirudi, beraz, Putnamek intentzionalitatearen gaiari egiten dion ekarpenaren neurria, izaera eta garapena zehazki ikertzea merezi duen zeregina dela gaur. Are gehiago, merezi duena bakarrik ez, zeregin garrantzitsua ere bada, arrazoi bat baino gehiagorengatik. Arrazoi horietako bat, filosofia analitiko post-oxfordiar eta post-positibista logikoan Putnamek daukan garran- 
tzi orokorraz harago, honako hau da: gai honen inguruko ikuskera garaikide nagusiarekiko - alegia, intentzionalitatearen eta naturalismoaren arteko tentsioa askatzen saiatzen den ikuskerarekiko- Putnamek daukan jarrera kritikoa, eta baita jarrera kritiko horren erradikaltasuna ere. Izan ere, denbora batez jarrera nagusi hori partekatu eta gero, zera ondorioztatzera iritsi zen Putnam: ebatzi nahi duen auziaren beraren formulazio guztiz desegoki batean oinarritzen dela, eta formulazio hori tradizio filosofiko luze batetik jaso duela, jatorria aro klasikoan daukan tradizio batetik. Labur esateko, eta nahiz eta ez duen adierazpen hau bera erabiltzen, baizik eta honi lotua dagoen «kartesianismo-gehi-fisikalismo» terminoa, Putnamek defendatzen $\mathrm{du}$ naturalismora jotzen duen intentzionalitatearen arazoaren gaur egungo hurbilketa «intentzionalismo kartesiar» esan diezaiokegun eta teorikoki antzua den horren mende dagoela. Bere iritziz, intentzionalismo kartesiar horrek «kale itsu» ${ }^{1}$ batera (ikus Putnam 1987: 16) eraman du, hasieratik, intentzionalitatearen arazoaren irtenbidearen bilaketa — hau da, «trataezin» 2 (ibid: 13) bihurtzen duen itxaropenik gabeko norabide teoriko batera-, eta arazoari norabide naturalista ematen dion berbideratze garaikidea ez da kale itsu horretara garamatzan pauso bat gehiago besterik. Horrela, Putnamen kritikak irismen handia du; izan ere, kritika zuzena bada, zera esan nahiko $\mathrm{du}$ : intentzionalitatearen ideia, forma batean edo bestean (izan intentzionalitate pertzeptiboa, ekiteko intentzioa, intentzionalitate kolektiboa...), naturalismoarekin bateragarri eginez eta horrela kognizioaren zientzia naturalista batentzat esanguratsu eginez, lehenago aipatutako tentsioa askatzen saiatzen diren gaurko ahalegin guztiak bereziki porrotera kondenatuta daudela. Gauza garrantzitsua da, beraz, bere balio erreala neurtzea eta, horretarako, aurrena bere esanahi zehatza argitzea.

Nolanahi ere, azpimarratu beharko litzateke Putnamek ez duela esaten intentzionalitatearen eta naturalismoaren ideien arteko tentsioaren gaineko ardura bera legitimoa ez denik, eta, are gehiago, berak ere baduela tentsio hori askatzeko anbizioa, gaur egun nagusi den jarrera bateratzaileari jarraituz. Aipatzen duena zera da, halako anbizioa bestelako bide naturalista bat hartuz bakarrik bete daitekeela; hamazazpigarren mendean jasotako oinarrizko uste kartesiar ilunetatik askatuko den bidea, eta aro klasikoak baztertu aurreko tradizio aristoteliarrarekin berriro lotuko dena, hain zuzen (ikus Putnam 1999). Labur esanda, Putnamek hobesten duena intentzionalismo naturalista mota alternatibo bat da, orientazio ez-kartesiarra ezaugarri nagusi duena. Eta ezaugarri hori arrazoi bat gehiago da bere analisi kritikoari eta bere proposamen eraikitzaileari, biei, nahikoa arreta jartzeko. Izan ere, horren bidez Putnamek oihartzun egiten dio, zuzenean, gaur egun kognizioaren teoriarako $4 \mathrm{E}$ paradigma baten bilaketa esan ohi zaionaren kezka nagu-

\footnotetext{
1 «blind alley» (Putnam 1987: 16)

2 «intractable» (ibid: 13$)$
} 
siari, zeinaren azken batasuna, zalantzarik gabe, kartesiarra ez den azalpen kognitiboa bilatzean datzan (ikus, bereziki, Wheeler 2005). Izatez, bere lana teorizazio kognitiboaren korronte berri honen aurrerapen partzialtzat agertzen da, eta harritzekoa da aitzindari-lan hori ez zaiola onartu $4 \mathrm{E}$ teorikoen aldetik (Alva Noeren salbuespenarekin seguru asko, merezitako onarpena egiten baitio —ikus Noe 2012, bere ikuskera propioen garapenean daukan eraginaren izaera zehaztu gabe, nolanahi ere-). Are eta interesgarriagoa den aitzindaritza, zuzenean erlazionatzen baita $4 \mathrm{E}$ mugimenduan oraindik hastapenetako ikertze-egoeran dauden bi puntu teorikorekin: alegia, intentzionalitate propietatearen ikuskera ez brentaniar bat moldatzearen aukerarekin (ikus Roy 2016) eta pragmatismo kognitiboaren ideiaren emankortasun eta izaera zehatzarekin (ikus Roy 2013 eta Roy 2015).

Nire helburu bakarra, hemen, hasierako pauso batzuk egitea da, argitzeko zergatik jotzen duen Putnamek intentzionalitatearen arazoa trataezintzat hamazazpigarren mendean jaio zen tradizio teorikoaren testuinguruan, zeina gaur egungo gaiaren inguruko interesaren berpiztea barne hartzen ikusten duen berak. Horrela adierazita, helburu hori anbiguoa da. Alde batetik, uler daiteke arazoaren interpretazio tradizionalak mugatzen duen irtenbideen eremuaren parte diren irtenbideetako bakoitza bere horretan desegoki egiten duen horri buruzko gisara; beste modu batera esanda, arazoaren trataezintasuna zertan datzan argitu nahiko balu bezala. Halere, uler daiteke modu sakon eta orokorragoan ere, espazio hau guztia desegoki egiten duen horri buruzkoa balitz bezala; beste modu batean esanda, trataezintasunaren arazoa zertan oinarritzen den argitu nahiko balu bezala. Eta horixe da nik hobetsiko dudan auziaren alderdia. Izan ere, Putnamen iritziak ulertu eta ebaluatzeko, zera argitu behar da aurrena: haren ustetan hamazazpigarren mendetik (eta gaurdaino) intentzionalitatearen arazoari konponbidea bilatzeko saiakera gidatu duten lerroak kutsatu dituzten oinarrizko uste kartesiar horien izaera.

Nolanahi ere, esan behar da zerbait honi buruz: zertan datzan intentzionalitatearen arazoaren ikuskera tradizionalaren trataezintasuna. Badirudi Putnamek pentsatzen duela, horrela interpretatuta, hiru konponbide mota nagusi eskaintzen dituela, eta ikusi dela denak antzuak direla eta ez dutela ebazpen baterako itxaropenik sortzen. Lehenengoak intentzionalitatea propietate oinarrizko eta espezifikotzat ikusten du, mundu naturala ezaugarritzeko egokiak diren beste guztietatik deskonektatua, eta substantzia espezifiko baten beharrean bezala. Hala ere, soluzio dualista hori hutsal suertatu da, bere ustez, «ezer konpontzen ez duen ${ }^{3}$ (ikus Putnam 1981: 2) deus ex machina bat postulatuz eta, gainera, «fenomenologia txarra eta nahaste-borraste kontzeptuala ${ }^{4}$ da (ikus Putnam 1981: 2). Putnamen laburpen-hitzetan

\footnotetext{
3 «solves nothing» (Putnam 1981: 2)

4 «bad phenomenology and conceptual confusion» (Putnam 1981: 2)
} 
esanda: «ez dugu lortu pentsamendua 'substantzia' misteriotsu baten, gogoaren, propietate primitibo bat besterik ez dela dioen teoriari inolako edukirik ematea ${ }^{5}$ (ikus Putnam 1987: 13). Bigarren konponbidea eliminatibismo intentzionalarena da, intentzionalitatea alferrikako aierua dela dioen ideia, hari esleitzen zaion deskribapen- eta azalpen-lan guztia propietate naturalen artean sartzen diren —edota haien artean integratzeko errazak diren- propietateei esleitzea emankorragoa dela dioena. Intentzionalitatearen ideia ezabatzea errealismoaren ideiaren kontra doa, nolanahi ere, erreferentzia-propietatea (errealismoaren funtsezko osagaia dena) ezabatzearen pareko baita; eta, seguru asko, errealismoak ezagutzaren arrakastaren (eta, orokorrago, giza jokabidearen) konponbide sinesgarri bakarra eskaintzen duela da Putnamen uste ziurrena, 1978ko bere Meaning and the Moral Science (Putnam 1978) liburuan defendatzen denez. Existitzen den kanpoko mundu bati mentalki erreferitzen diogula dioen ideia baztertzea zerbait absurdoa da, beraz, berarentzat, eta, gainera, sen onak dioenetik urruti geratzen den zerbait. Baina zera da zailtasuna, intentzionalitatearen arazoaren ikerketan egin den berbideratze naturalista garaikideak erabiltzen dituen sen onaren araberako errealismo intentzionalaren oinarrizko intuizioei leial eusteko saiakera guztiek, intentzionalitatea «maila altuan deribatutako fenomeno fisikotzat» ${ }^{6}$ (ikus Putnam

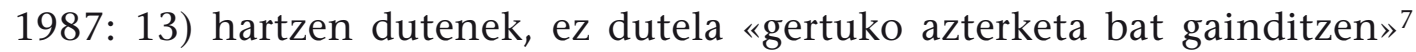
(ibid.), eta ez dutela lortzen, hortaz, euren asmoak betetzea. Horri dagokionez Putnamek daukan kexa nagusia honako hau da: intentzionalitatearen erredukzio psiko-neuralaren aurka egiten duen gauzagarritasun multiplearen argudio horrexek berak aurka egiten diola, baita ere, intentzionalitatea bigarren mailako propietate funtzional batekin identifikatzeari, hirurogeiko hamarkadaren amaieran berak proposatu zuen moduan (ikus Putnam 1985): «'Maila intentzionala', dio, ez da 'maila konputazionalera' erreduzigarria, 'maila fisikora' baino gehiago ${ }^{8}$ (ikus Putnam 1987: 15).

Lehenago azpimarratu bezala, bere kritikaren erradikaltasuna analisia maila sakonagora bultzatzean datza, eta arazoari forma ematen dioten oinarrizko usteekin azaltzen diren zailtasun horiei guztiei jatorri komun bat bilatzean. Zein dira oinarrizko uste oker horiek?

Horietako bat ez da intentzionalitate propietatearen errealitatea sen onaren mailan onartzea. Izan ere, intentzionalitatea asmakizun linguistiko hutsa balitz, inongo errealitaterik egokitzen ez zaiona, edo gutxienez ez errealitate zehatzik, ez litzateke izango ebatzi beharreko intentzionalitatearen arazorik

5 «We have not succeeded in giving the theory that thought is just a primitive property of a mysterious 'substance', mind, any content.» (Putnam 1987: 13)

6 «a highly derived physical phenomen[on] in some way» (Putnam 1987: 13)

7 «withstand close inspection» (ibid.)

8 «The 'intentional level' is simply not reducible to the 'computational level' any more than it is to the 'physical level'.» (Putnam 1987: 15) 
edo arazo zehatzik; ezta maila teorikoan ere, ezabatze bidez. Baina Putnamek ez du halako disoluzio-estrategia baten alde egiten, intentzionalitatea sen onaren aieru sendotzat ikusten baitu, eta ergelkeria litzateke hori ukatzea, edo munduaren «irudi zientifikotik» modu batera edo bestera kanporatzen saiatzea.

Arazoa ez da, ezta ere, gaizki-ulertu erradikalen bat gertatu dela ulertzen saiatzerakoan zertan datzan sen onaren aieru hori bere mailarik orokorrenean. Putnamek ez dio inoiz zentzu horretan mespretxurik egiten sen onari eta, halaber, ez du salatzen intentzionalitatearen teorikoek hamazazpigarren mendeaz geroztik sen ona alde batera utzi dutenik. Egia dena da harrigarriki lauso aritzen dela intentzionalitatearen izaerari buruz, eta, aldi berean, adostasun handia azaltzen duela, zentzu horretan, eztabaida garaikidearekin, ados azaltzen baita intentzionalitatea buruzkotasun (aboutness) erlaziotzat azaltzearekin, munduari erreferentzia egitearen erlazio gisan ere parafraseatuz. Egiazki, hitzaren bi zentzu desberdin baina konbergente bereiz daitezke bere idatzietan. Badago aurrena zentzu zorrotz bat, Brentanorengandik datorkiguna, gogo-egoerek munduari erreferentzia egiteko daukaten propietate zehatzarekin zerikusia daukana (adibidez, Putnam 1981: 17). Egia esan, zentzu zorrotz hori bitan banatzen da: batzuetan, Putnamek, intentzionalitateaz, zehazki, gogo-egoerek erakusten duten munduari erreferentzia egiteko gaitasuna designatzen du; beste batzuetan, fenomeno hori azaltzeko brentaniarrek hipotesi gisa jartzen duten propietate «magiko» espezifikoa. Eta badago zentzu zabalago bat, mundu-erreferentzia forma guztiak (zeinuen bidezkoa, irudien bidezkoa...) barne hartzen dituena, edo mundu-erreferentzia eurekin dakarten propietateak (egia, adibidez), edo baita mundu-erreferentziarekin lotutako propietateak ere (esanahia izatea, adibidez) (ikus, bereziki, Putnam 1988: 1).

Eta ez da, ezta ere, bere ustez, okerra pentsatzea intentzionalitate propietate honek, estatus eta izaera ontologiko ez-arazotsua izanda ere, auzi zehatz bat planteatzen duenik. Beste modu batera esanda, intentzionalitatearen arazoa ez da trataezina bona fide propietate bati buruzko arazo ilusorioa izateagatik.

Trataezintasun hori ez da gertatzen salatutako tradizio filosofikoan egozten zitzaion betekizun nagusiagatik ere. Nahiz eta bestela lirudikeen, Putnamek ere intentzionalitatearen arazoa nagusitzat dauka, ez periferikotzat, eta zentzu honetan ezin da hartu «ez-hain-guztiz-intentzionalitatearen-teoriko»tzat, lehenago aipatutako autoreekin konparatuta. Kontrako irudipena datorkigu zeharka bakarrik heltzen diolako, bere ardura oinarrizkoena errealismoaren auziaren estatusa delako, eta egia korrespondentzia gisan ulertzearena, aro post-tarskiar batean (adibidez, Putnam 1986: 1. hitzaldia; Putnam 1987: 1. kapitulua). Gai horrek, nolanahi ere, munduari erreferentzia egitearen gaia barne hartzen du, eta, beraz, intentzionalitatearena bietan, zentzu zabal 
eta estuan, Putnamek esplizituki onartzen duen bezala Representation and Realityn: «Gatazka honetan [errealismoaren antinomiena] aurrera egin nahian, azkar aurkitu nuen intentzionalitatearen auziari leku nagusi bat zegokiola»9 (ikus Putnam 1983: 108).

Azkenik, trataezintasuna ez dator arazoaren muina ulertzeko modutik; hau da, arazoa hamazazpigarren mendean jaiotako tradizioaren testuinguruan ulertzen duten teorikoei Putnamek ez die leporatzen arazoak sortzen dituen zailtasunak gaizki identifikatu dituztenik. Esan daiteke Putnamek hiru alderdi nagusi desberdintzen dituela hor. Aurrena, intentzionalitatearen izaeraren auzia dator: zertan datza zerbaiti buruz izatea? (ikus Putnam 1981: 43). Auzi hori kontu handiz desberdindu behar da buruzkotasunaren determinazioarenetik (edo «finkatzearenetik»-ikus Putnam 1981: 24-); alegia, ulertzea zergatik beste zerbaiti buruzkoa den zerbait hari berari buruzkoa den eta ez beste zerbaiti buruzkoa. Putnamek dioen moduan: «... erreferentzia nola zehazten den azaltzen duen teoria bat ez da erreferentzia zer den azaltzen duen teoria bat» ${ }^{10}$ (Putnam 1978: 58). Azkenik, intentzionalitatearen posibilitatearen — hobe esanda, posibilitatearen baldintzen- auzia dago; Putnamen iritziz, izatez Kantengandik dator, eta horrela formulatzen du: «Nola da posible intentzionalitatea, erreferentzia?» ${ }^{11}$ (ikus Putnam 1981: 43). Eta, zalantzarik gabe, hirugarren galdera hori da denetan nagusia berarentzat, eta beste biei eman behar zaizkien erantzunak gidatzen ditu.

Putnamek salatzen dituen oinarrizko uste oker nagusiak bestelakoak dira, eta, azken buruan, hiru kopuruz. Garrantzi gutxien duena da «[intentzionalitatearen] halako teoria batek posible izan behar duelako oinarrizko ustea bera», Putnamek «guztiz okertzat» 12 (ikus Putnam 1988: 109) jotzen duena; ostera, argudiatuz «fenomeno desberdin batzuk nolabait azaltzea posible egingo duen irudi bat» ${ }^{13}$ (ibid.) bakarrik eskain dezakegula. Nolanahi ere, oinarrizko uste horrek paper oso txikia soilik jokatzen du arazoaren formulazio tradizionala baztertzeko dauzkan arrazoien artean, eta, gainera, bere kritiken jomuga nagusi diren beste bi oinarrizko usteetatik independentea da.

Nagusia, dudarik gabe, Putnamek famatuki «errealismo metafisiko» esan zion onarpenarena da, nahiz eta azken urteetan halako etiketaren egokitasunaren inguruan zalantzak azaldu zituen (ikus Putnam 2016: 24). Eta nagusia da, hasteko, intentzionalitatearen arazoari egiten zaion hurbilke-

\footnotetext{
9 «In working my way through this conflict [that of the antinomies of realism], I found early on that the question of intentionality held a central position.» (Putnam 1983: 108)

$10 \ll \ldots$ a theory of how reference is specified isn't a theory of what reference is.» (Putnam 1978: 58)

11 «How is intentionality, reference, possible?» (Putnam 1981: 43)

12 «the very assumption that such a theory [of intentionality] must be possible [is] wholly wrong.» (Putnam 1988: 109)

13 «a picture that enables us to make some sense of a variety of phenomena» (ibid.)
} 
tak errealismo metafisikoaren tesia aurresuposatzen duelako; tesi hori lehenago aipatutako hiru zailtasun mota nagusietan topatzen da, eta, beraz, ebatzi nahi duen auzia bera trataezin bihurtzen du. Reason, Truth and Historyn (Putnam 1981) ematen da baieztapen nagusi horren lehenengo erabateko adierazpena. Errealismo metafisikoaren kontzepzio putnamiarra, berak sarri Objektibismo deritzona, zehaztea ohar honen helburuez harago doa. Esan dezagun, besterik gabe, adierazpen horrekin Putnamek izendatzen duela, ez bakarrik subjektu ezagutzaileaz kanpo errealitate objektibo bat badagoela dioen ideia, baizik eta baita hartaz eman daitekeen egiazko ezaugarritze epistemiko bakarra dagoela ere, zeinaren egia nagusiki korrespondentzia-forma batean datzan. Errealismo metafisikoaren edo objektibismoaren tesi nagusia da, hortaz, propietate intrintsekoaren nozioa — «zerbaitek bere baitan daukan propietate bat, hizkuntzak edo gogoak eginiko edozein ekarpenez apartekoa»14 (ikus Putnam 1987: 8) gisan ulertuta- legitimoki egozten zaiola errealitate externoari. Eta, horregatik, nozio hori da intentzionalitatearen trataezintasunean adierazten den "gaitzaren sustrai sistemiko sakona» ${ }^{15}$ osatzen duena. Eta horregatik jotzen du beharrezko Putnamek hura ordezkatzea, ez irrealismo metafisikoaren nozio batekin, baizik eta propietate intrintsekoaren nozioaz libre egongo den errealismo nozio batekin, zeinarentzat 1976an «errealismo interno» adierazpena proposatu zuen, eta, bere bidean aurrerago, «errealismo pragmatiko» ${ }^{16}$ (ikus Putnam 1987: 17, eta Putnam 1988: 114), tradizio pragmatistan (eta, bereziki, William James eta John Deweyren ideie$\tan )$ agertzen zela irizten ziolako. Propietate intrintsekoaren ideia alde batera uztea errealismoa erlatibitatearen nozioarekin lotzea da; zehazki, erlatibitate kontzeptualarenarekin lotzea. «Errealismo internoa, dio Putnamek, azken buruan da azpimarratzea errealismoa ez dela bateraezina erlatibitate kontzeptualarekin ${ }^{17}$ (ikus Putnam 1987: 10). Zehatzagoa litzateke esatea errealismoa zentzuzkoa dela bakarrik erlatibismo kontzeptualaren ideiarekin lotzen denean. Baieztapen horrek bi inplikazio dakartza zuzenean, Putnamen iritziz. Lehenengoa da objektuaren nozioa zentzugabekeria hutsa dela sistema kontzeptual baten nozioari lotuta ematen ez bada: zerbait objektu bat da sistema kontzeptual batekin erlazioan soilik. Bigarrena da berdin legitimoak diren sistema kontzeptual desberdinak daudela, eta, beraz, berdin legitimoak diren objektu-sistema desberdinak.

Hirugarren oinarrizko uste okerra pertzepzioaren inguruko zeharkako errealismoaren doitasunarena da. Oinarrizko uste horrek objektibismoaren tesiarekin daukan lotura geroago identifikatu zuen Putnamek, zehazki The

14 «a property something has in itself, apart from any contribution made by language or by the mind.» (Putnam 1987: 8)

15 «the deep systematic root of the disease».

16 «pragmatic realism» (Putnam 1987: 17 eta Putnam 1988: 114)

17 «Internal realism is at bottom just the insistence that realism is not incompatible with conceptual relativity.» (Putnam 1987: 10) 
Threefold Core (Putnam 1999) liburuan, nahiz eta The Many Faces of Realism liburuak jada pauso garrantzitsua egin zuen identifikazio horren norabidean, 1987an. Zera dio tesiak: pertzepzioa ez dela hautematen diren objektuekin berekin den erlazio kognitibo zuzen bat, baizik eta zentzumenezko izaera duten tarteko entitate batzuen bitartez (sense data) ematen dela, normalean pertzibitzen diren objektuek kausatzen dituztela pentsatu ohi direnak. Oinarrizko uste hori da, zehazki, Putnamek esplizituki kartesiartzat jotzen duena (Putnam 1999: 9), eta horren bertsio materialista da berak espezifikoki kartesianismo-gehi-fisikalismo deritzana (ibid.: 19). Horrela, Putnam errealismo internoaz daukan hasierako kontzeptua berraztertu beharrean aurkitzen da: bere buruari esplizituki aurpegiratzen dio ez duela hartatik kanpo utzi zeharkako errealismoaren ideia, eta horren ordez errealismo zuzenaren ideia sartzen du, berak «errealismo natural» ${ }^{18}$ (ikus Putnam 1999: 10) ere baderitzana. Beste modu batera esanda, errealismo internoa anti-objektibismoaren eta errealismo zuzenaren konbinazio bihurtzen da, eta, horrela, hobetsi egiten da zabalagoa den errealismo pragmatikoaren etiketara aldatzea.

Putnamek erakusten du azken bi oinarrizko uste horiek intentzionalitatearen arazoaren trataezintasuna azaltzen dutela; ez dut argudiatze hori berreraikiko, ezta azalduko ere nola trataezintasun hori ustez desagertzen den horiek bere errealismo pragmatikoaren bi osagai nagusiekin ordezkatzen ditugunean. Izan ere, nahikoa esan da aurretiazko ikerketa hau motibatu eta ireki duen galderari (non kokatzen da benetan Putnam eztabaida intentzionalistari dagokionez, eta nola ulertu beharko genuke horri egiten dion ekarpen orokorra?) erantzuna bilatze aldera oinarrizkoak baina erabakigarriak diren elementu batzuk aurkitzeko.

Lehenik eta behin, argitu behar da Putnamek intentzionalitatearen arazoari aurre egiten diola arazo hori bere kezka nagusia den errealitatearen eta egiaren auzi metafisikoaren erdigunean bertan dagoelako. Ondorioz, guztiz hartzen du parte eztabaida intentzionalista garaikidean, eta sakonki egiten $\mathrm{du}$, gainera, erlazio intentzionalaren posibilitatearen baldintzen auziaren inguruan ohikoa ez den enfasia jartzen duelako. Nolanahi ere, protagonista interno izatetik protagonista externo izatera pasa nahi duen parte-hartzailetzat ikusi beharko litzateke eztabaidan. Izan ere, aurrera egin ahala, auzitan jartzen du eztabaidaren markoa, bere ustetan okerra dena baina ezbaian jartzen ez dena, eta Representation and Realityn, arrazoi osoz, «intentzionalitatearen azalpen errealista zientifiko» ${ }^{19}$ baten bilaketa deritzana (Putnam 1988: 108), eta intentzionalitatearen azalpen errealista zuzen eta objektibista baten bilaketatzat jo daitekeena. Eta, nahiz eta Putnamen ardura nagusiak, liburu honetan, halako azalpen baten bertsio naturalistarekin daukan zerikusia, de-

\footnotetext{
18 «natural realism» (Putnam 1999: 10)

19 «scientific realist account of intentionality» (Putnam 1988: 108)
} 
fendatzen duena da ez dela nahikoa bertsio materialista horren inguruan biltzen diren zailtasunak zehatz-mehatz erakustea, euren azken jatorria errealismo zientifikoan baitaukate, zeinetan oinarritzen den bertsio materialista hori eta zeina partekatzen duen bertsio ez materialistekin; edo, bere hitzekin esatearren, «Objektibismo Modernoa Materialismo bihurtu delako, besterik gabe» ${ }^{20}$ (Putnam 1987: 13). Lan horretan bertan aurkeztutako bereizketa bat erabiliz, esan liteke Putnam eztabaidaren protagonista interno bat dela, «errealista zientifikoaren ikuspegiaren barnetik» ${ }^{21}$ (Putnam 1988: 108) parte hartzen duen heinean eztabaidan, aurrena positiboki eta gero negatiboki; eta protagonista externoa, berriz, errealismo pragmatikoaren ikuspegi alternatibotik parte hartzen duen heinean.

Intentzionalitatearen arazoari egiten dion ekarpenaren muina, beraz, ulertu behar da ezinezkotasunaren teorema baten formulaziotzat, esanez arazo hau ezin dela ebatzi errealismo zuzen eta metafisikoari uko egin gabe, eta errealismo pragmatikoa onartu gabe. Eta, horrekin, uzten digun benetako zeregina da zehaztea zein puntutaraino den onargarria ezinezkotasunaren teorema hori.

Zeregin hori ez da batere erraza. Putnamen teorema sostengatzen duen eraikuntza teorikoa aberatsa eta konplexua da, eta izaeraz historikoak, kritikoak eta teorikoak diren azpigai askori buruzko hainbat erabaki barne hartzen ditu. Horiek denek uzten dute eztabaidarako tartea, eta sor diezaiekete zailtasunik Putnamen ondorioei. Gainera, eraikuntza horri aurkezpen sistematiko bat falta zaio, Putnamen liburu guztiak ez baitira artikulu-bildumak besterik. Eraikuntza horren alderdi batzuek garapen teknikoago eta zehatzagoa ere behar dute; bereziki, alderdi historikoek.

Nolanahi ere, zeregin nekeza da hori, teorema honek planteatzen dituen zailtasun batzuen tamaina eta sakona ikusirik. Intentzionalitatearen naturalizazioa bilatzen duen proiektu osoa, berrogeita hamarreko hamarkadaren erdialdetik hona garatu den forman, benetan alde batera utzi beharko al genuke, adibidez? Edo zentzugabekeriatzat jo behar al genuke zerbait existitzen delako ustea, eta existitzen dena, hori hautemateko erabili den edozein sistema kontzeptual gorabehera, dela den bezalakoa dioena? Eta zuzena al da pentsatzea, Putnamek defendatzen duen moduan, tradizio husserliarrak oinarrizko ekarpenak egin dituela honi dagokionez (ikus Roy 1999), eta berdin tradizio pragmatistak?

Pertsonalki, ez nago batere ziur puntu erabakigarri horietako bat baino gehiagotan Putnami jarrai ote diezaiokegun. Izatez, susmo sendoa daukat motz gelditzen dela bere kritikaren funtsezko alderdi batzuetan. Eta, bere-

20 «Modern Objectivism has simply become Materialism.» (Putnam 1987: 13)

21 «within the scientific realist's own perspective» (Putnam 1988: 108) 
ziki, uste dut eztabaida intentzionalista garaikideko alderdi handienarekin bat egiten jarraitzen duela, intentzionalitate propietatearen izaerarik sakonena gaizki ulertuz, hura existitzen den mundu bati erreferentzia egiteko gaitasunera murriztuz, eta objektifikatzeko gaitasuntzat ulertu zuen bere jatorri brentaniar eta eskolastikoaz ahaztuz; hau da, zerbaitekin objektu gisan erlazionatzea, izan hura erreala edo irreala (ikus Roy 2016). Eta, horregatik, ez dela batere ziurra intentzionalitatearen arazoa errealismoaren arazoari hain estu lotua dagoenik, ezen hari ebazpena aurkitzea errealismoa ulertzeko gure modua eraldatzetik bakarrik etor baitaiteke.

\section{Erreferentzia bibliografikoak}

NoË, Alva (2012), Varieties of presence. Cambridge, Mass.: Harvard University Press.

Putnam, Hilary (1967), «The Nature of Mental States». In H. Putnam (1975), Mind, language, and reality; Philosophical Papers 2. Cambridge: Cambridge University Press, 362-385.

Putnam, Hilary (1975), «The Meaning of Meaning». In H. Putnam (1975), Mind, language, and reality; Philosophical Papers 2. Cambridge: Cambridge University Press, 215-271.

Putnam, Hilary (1978), Meaning and the moral sciences. Londres: Routledge \& K. Paul.

Putnam, Hilary (1981), Reason, Truth and History. Cambridge: Cambridge University Press.

Putnam, Hilary (1983), Realism and reason. Cambridge: Cambridge University Press.

Putnam, Hilary (1987), The many faces of realism. La Salle, Illinois: Open Court.

Putnam, Hilary (1988), Representation and Reality. Cambridge: MIT Press.

Putnam, Hilary \& CONANT, James (1990), Realism with a human face. Cambridge, Mass.: Harvard University Press.

Putnam, Hilary (1992), Renewing philosophy. Cambridge, Mass.: Harvard University Press.

Putnam, Hilary \& Conant, James (1994), Words and life. Cambridge, Mass.: Harvard University Press.

Putnam, Hilary (1999), The threefold cord: mind, body, and world. New York: Columbia University Press.

Putnam, Hilary \& DE CARo, Mario (2016), Naturalism, Realism and Normativity. Cambridge, Mass.: Harvard University Press.

Roy, Jean-Michel (2013), «Pragmatisme cognitif et énactivisme». Intellectica [Ale berezia: P. Steiner (arg.), Pragmatisme(s) et Sciences Cognitives] 2/60: 69-89.

Roy, Jean-Michel (2015), «Anti-Cartesianism and Anti-Brentanism: The Problem of Anti-Representationalist Intentionalism». Spindel Supplement: The Southern Journal of Philosophy 53 (1): 90-125.

Roy, Jean-Michel (2016), [Txineraz] «The problem of cognitive pragmatism». Philosophical Analysis. Shanghaï: Shanghaï Academy of Social Sciences.

WHEELER, Michael (2005), Reconstructing the cognitive world: the next step. Cambridge, Mass.: MIT Press. 